\title{
Influence of diabetes mellitus on the mineralization ability of two endodontic materials
}

\begin{abstract}
João Eduardo GOMES-FILHO(a) Índia Olinta de Azevedo QUEIROZ(a) Simone WATANABE ${ }^{(b)}$ Luciano Tavares Angelo CINTRA (b) Edilson ERVOLINO(b)
\end{abstract}

(a) Univ. Estadual Paulista - UNESP, Araçatuba School of Dentistry, Department of Endodontics, Araçatuba, SP, Brazil.

(b)Univ. Estaudal Paulista - UNESP, Araçatuba School of Dentistry, Department of Basic Science, Araçatuva, SP, Brazil.
Declaration of Interests: The authors certify that they have no commercial or associative interest that represents a conflict of interest in connection with the manuscript.

\section{Corresponding Author:}

Índia Olinta de Azevedo Queiroz

E-mail: indiaodonto@gmail.com

DOI: 10.1590/1807-3107BOR-2016.vol30.0025

Submitted: Aug 03, 2015

Accepted for publication: Oct 01, 2015

Last revision: Nov 24, 2015

\begin{abstract}
The aim of this study was to evaluate the influence of diabetes mellitus on tissue response and mineralization ability of Sealapex ${ }^{\circledR}$ and MTA Fillapex ${ }^{\circledR}$ sealers. Twenty-four Wistar rats were divided into two groups: diabetic and non-diabetic. The materials were placed in polyethylene tubes and implanted into dorsal connective tissue of rats for 7 and 30 days. Six animals from each group received injection of calcein, alizarin, and oxytetracycline on days 7, 14, and 21, respectively. The animals were killed after 7 and 30 days and specimens were prepared for histologic analysis by staining with hematoxylin and eosin or Von Kossa or left unstained for polarized light or fluorescence microscopy. On day 7, inflammatory reactions were characterized. Moderate inflammatory responses were observed for all groups and on day 30, a mild inflammatory response against MTA Fillapex ${ }^{\circledR}$ and a moderate inflammatory response against Sealape ${ }^{\circledast}$ were observed. Von Kossa-positive structures were observed in response to both materials and birefringent structures were observed upon polarized light analysis; these had no relation to the diabetic condition ( $p>0.05)$. The fluorescence intensity was unaffected in diabetic rats $(p>0.05)$. In conclusion, diabetes mellitus did not influence the tissue response or mineralization stimulated by Sealapex ${ }^{\circledR}$ or MTA Fillapex ${ }^{\circledast}$.
\end{abstract}

Keywords: Diabetes Mellitus; Endodontics; Dental Materials.

\section{Introduction}

Diabetes mellitus (DM) is a metabolic disorder characterized by hyperglycemia resulting from defects in insulin secretion, insulin action, or both and can manifest itself as type 1 or $2 .{ }^{1}$ Hyperglycemia elevates levels of systemic inflammation markers ${ }^{2}$ and alters various functions of the immune system, ${ }^{3}$ resulting in wound healing problems and systemic and oral manifestations. ${ }^{4,5}$ The compromised immune responses contribute to increased susceptibility to infections ${ }^{2,3}$ and leads to predisposition to a wide spectrum of oral diseases including pulpal and periapical infections. ${ }^{4,5}$ Fouad $^{6}$ showed that DM may be a modulating factor of endodontic infections and may compromise the healing process of periapical tissues.

Endodontic therapy is an important element in the renewal of apical and periapical tissues. The success of this therapy depends on cleaning and shaping of the root canal system, control of pathogenic microorganisms, 
as well as root canal filling with proper material such as gutta-percha and sealer.

Root canal sealers with different formulations have been studied. Since the chemical composition of sealers can positively or negatively influence the outcome of endodontic therapy, ${ }^{7}$ the sealers should be carefully studied prior to clinical application.

Sealapex ${ }^{\circledast}$ (Sybron Endo, Glendora, USA) is a calcium hydroxide-based sealer and has the ability to induce hard tissue formation at the apex after root canal obturation. ${ }^{8}$ It also has antimicrobial activity. ${ }^{9}$ Recently, the manufacturer modified the sealer formulation by changing the radiopacifier (i.e., from barium sulfate to bismuth trioxide) and increasing the shelf life of the sealer. ${ }^{10,11}$

MTA Fillapex ${ }^{\circledR}$ (Angelus, Londrina, Brazil) is an MTA-based sealer that has been introduced recently in the market. It contains MTA, salicylate resin, natural resin, resin diluent, bismuth oxide, and silica. Studies showed that MTA Fillapex ${ }^{\circledR}$ is biocompatible, has antimicrobial action, promotes adequate apical leakage prevention, and is capable of inducing mineralization. ${ }^{12,13,14}$

Since Sealape ${ }^{\circledast}$ and MTA Fillapex ${ }^{\circledast}$ have the ability to induce tissue mineralization and because DM is a disorder characterized by altered inflammatory response, the aim of the present study was to evaluate the influence of DM on tissue response and mineralization ability of these sealers in subcutaneous connective tissue of rats.

\section{Methodology}

Twenty-four male Wistar albino rats, aged between 3 and 4 months and weighing approximately 250-280 g, were used in the study. The rats were divided into two groups with 12 animals each: diabetic and non-diabetic. The animals were housed in temperature-controlled rooms with water and food ad libitum. All procedures were performed according to the guidelines of the Ethical Committee (protocol no. 0177-2011).

For diabetes induction, 12 animals received $150 \mathrm{mg} / \mathrm{kg}$ of Alloxan monohydrate (Sigma Aldrich Corp., St. Louis, USA) as a single intraperitoneal dose. ${ }^{15}$ Blood glucose was measured 3 days after injection to confirm hyperglycemia. Animals were considered diabetic if their glucose levels were higher than $250 \mathrm{mg} / \mathrm{dL}$ and the third day after injection was considered the first day of diabetes.

Sterile polyethylene tubes (Abbott Labs of Brazil, São Paulo, Brazil) with an internal diameter of $1.0 \mathrm{~mm}$, external diameter of $1.6 \mathrm{~mm}$, and length of $10.0 \mathrm{~mm}$ were used for experiments. Sealapex ${ }^{\circledR}$ (Sybron Endo) and MTA Fillapex ${ }^{\circledR}$ (Angelus) were prepared according to the manufacturer's recommendations and inserted into the tubes with a lentulo spiral (Maillefer Dentsply, Tulsa, USA). Twenty-four empty tubes were used as controls.

On day 1 of diabetes confirmation, animals were shaved under xylazine $(10 \mathrm{mg} / \mathrm{kg}$; Anasedan, Divisão Vetbrands Saúde Animal, São Paulo, Brazil) and 5\% ketamine anesthesia $(25 \mathrm{mg} / \mathrm{kg}$; Cetamin Syntec do Brasil, São Paulo, Brazil) and disinfected with 5\% iodine solution. The shaved backs received a $2 \mathrm{~cm}$ incision in a head-to-tail orientation with a number 15 Bard-ParkerTM blade (Bard-Parker, Dickinson \& Co., Franklin Lakes, USA). The skin was reflected, creating three pockets, two on the right side and one on left side of the incision. The tubes filled with sealers and empty tube were implanted into the spaces created with blunt dissection, and the incision was closed with 4/0 silk suture (Ethicon; Johnson \& Johnson, São Paulo, Brazil).

The fluorescent markers, calcein, alizarin red S and oxytetracycline hydrochloride (Sigma Aldrich Corp.) were injected intramuscularly at a dose of $20 \mathrm{mg} / \mathrm{kg}, 7,14$, and 21 days after implantation, respectively. ${ }^{16}$ These fluorochromes were used for evaluating the time sequence of calcium deposition in the tissue. These markers help in identifying where and when mineralization occurs during the process of ossification.

After 7 and 30 days from the implantation, animal's glucose blood levels were measured to confirm the induction of diabetes. The animals were killed by anesthetic overdose and the tubes along with the surrounding tissues were removed and fixed in $10 \%$ formalin solution at $\mathrm{pH}$ 7.0. ${ }^{17}$ The tubes were then bisected transversely, and both halves were cut again longitudinally with a sharp blade to allow the surfaces to come in contact with the processing solutions. The specimens were processed and embedded in 
glycol methacrylate (GMA) ${ }_{,}^{18}$ serially cut into $3 \mu \mathrm{m}$ sections, and stained with hematoxylin-eosin. The $10 \mu \mathrm{m}$ sections were stained according to Von Kossa technique or examined directly under polarized light. The $50 \mu \mathrm{m}$ sections were not stained for observation under a fluorescence microscope.

Inflammatory reactions in the tissue surrounding the material were evaluated as 0 , no or few inflammatory cells and no reaction; 1 , less than 25 cells and mild reaction; 2 between $25-125$ cells and moderate reaction; and 3, 125 or more cells and severe reaction. ${ }^{19}$ Fibrous capsules were considered to be thin when thickness was $<150 \mu \mathrm{m}$ and thick at $>150 \mu \mathrm{m}$. Necrosis and mineralization were recorded in $\mu \mathrm{m}^{2}$ using Leica Qwin software (Leica Microsystems, Wetzlar, Germany). An average value for each material was obtained from the sum of cells counted in 10 separate areas (magnification $x 400)$. Fluorescence intensity was measured at $534 \mathrm{~nm}, 357 \mathrm{~nm}$, and $368 \mathrm{~nm}$, for calcein, alizarin, and oxytetracycline, respectively by fluorescence microscopy (DM 4000B, Leica Microsystems). Fluorescence intensity was evaluated in an area of $150 \mu \mathrm{m} \times 700 \mu \mathrm{m}$ in the middle of tube opening and was recorded with LAS v4.1 software (Leica Applications Suite - version 4.1; Leica Microsystems). Results were statistically analyzed using ANOVA and Kruskal-Wallis tests for inflammatory reactions $(p<0.05)$ and Mann-Whitney tests for mineralization areas and fluorescence intensity $(\mathrm{p}<0.05)$.

\section{Results}

\section{Control (empty tubes)}

On day 7, a mild inflammatory cell infiltration consisting of macrophages and lymphocytes and thin fibrous capsule formation surrounding the tube were observed in both diabetic and non-diabetic groups. On day 30, a mild inflammatory response was observed in both non-diabetic (Figure 1) and diabetic groups (Figure 2).

The empty tubes were not positive for Von Kossa and no birefringent structures were observed under polarized light. Fluorescence intensity for calcein, alizarin red, and oxytetracycline was not observed for the diabetic and non-diabetic groups.

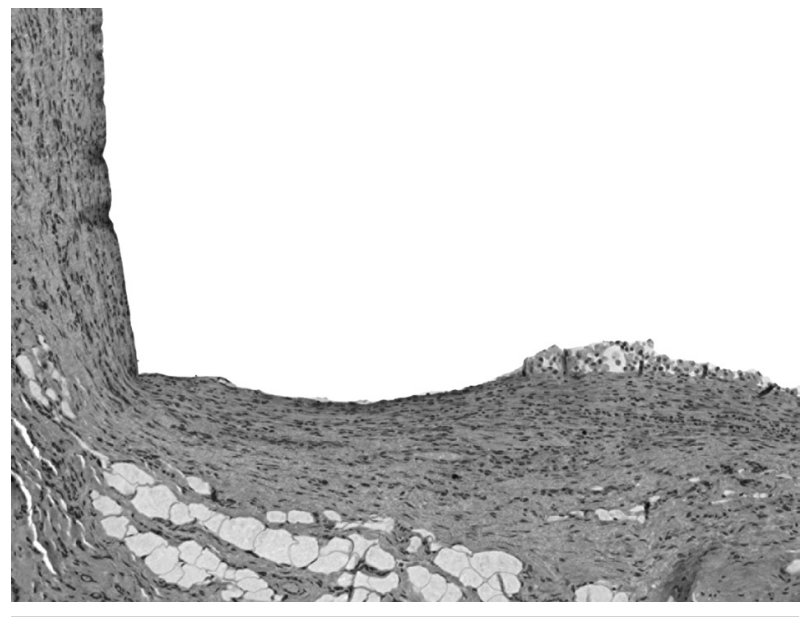

Figure 1. Inflammatory response in non-diabetic Control group at day 30: specimens showing thin fibrous capsule formation and mild inflammatory cell infiltration consisting of macrophages and lymphocytes (hematoxylin-eosin, 10X).

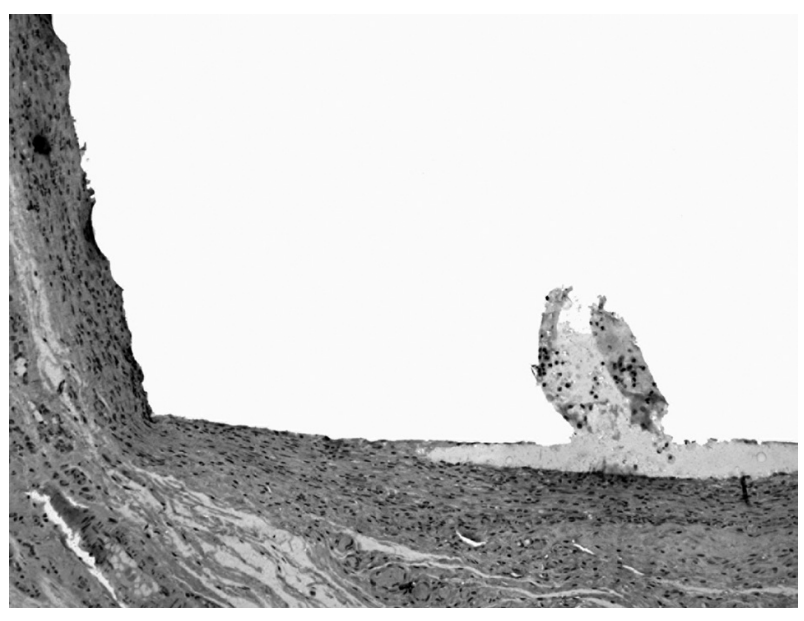

Figure 2. Inflammatory response in diabetic Control group at day 30: specimens showing thin fibrous capsule formation and mild inflammatory cell infiltration consisting of macrophages and lymphocytes (hematoxylin-eosin, 10X).

\section{Sealapex ${ }^{\circledR}$}

A moderate inflammatory cell infiltration consisting of macrophages and lymphocytes and thick fibrous capsule formation were observed on day 7 in both diabetic and non-diabetic groups. On day 30, a moderate inflammatory response was observed for non-diabetic (Figure 3) and diabetic groups (Figure 4). Granulations birefringent to polarized light and Von Kossa positivity were observed for all groups at days 7 and 30. Fluorescence intensity for calcein, alizarin red, and oxytetracycline was observed for both groups. 


\section{MTA Fillapex ${ }^{\circledR}$}

On day 7, a moderate inflammatory cell infiltration was observed for both groups. Granulations that were birefringent to polarized light and Von Kossa-positive were observed for all groups.

On day 30, a mild inflammatory infiltrate with few chronic inflammatory cells and thick fibrous capsule formation were observed for both non-diabetic (Figure 5) and diabetic groups (Figure 6). Granulations that were birefringent to polarized light and Von Kossa-positive were observed near the

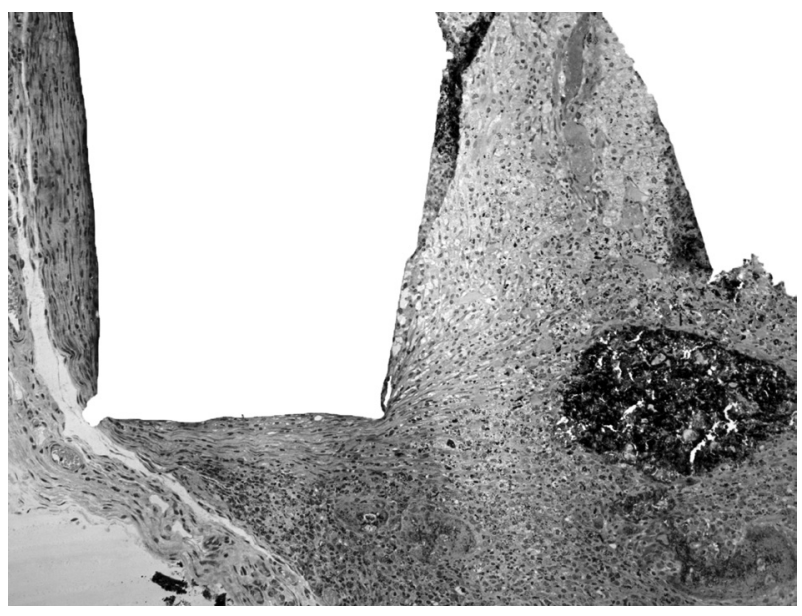

Figure 3. Inflammatory response in non-diabetic Sealapex group at day 30: moderate inflammatory cell infiltration (hematoxylin-eosin, 10X).

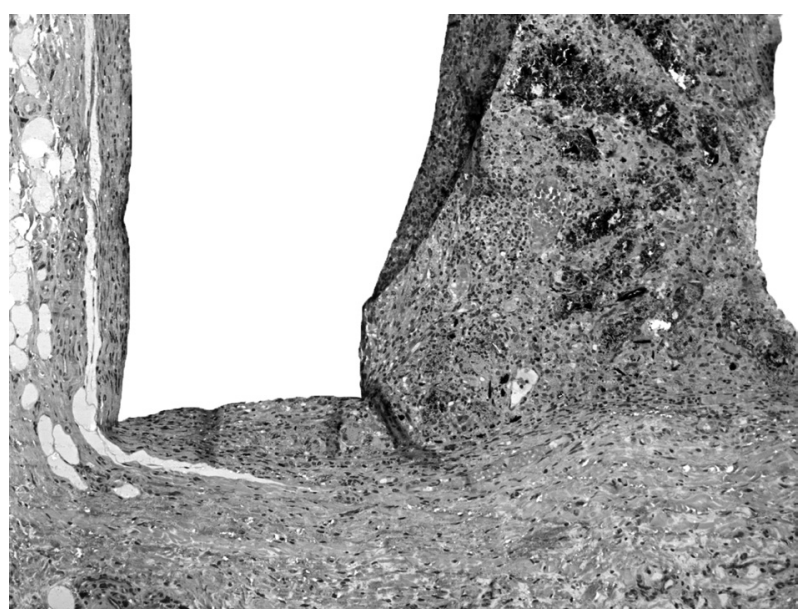

Figure 5. Inflammatory response in non-diabetic MTA Fillapex group at day 30: presence of a mild inflammatory cell infiltration consisting of macrophages and lymphocytes after 30 days (hematoxylin-eosin, 10X). tube openings. Fluorescence intensity for calcein, alizarin red, and oxytetracycline was observed.

\section{Comparison among the groups}

DM did not modify the inflammatory response to either control or the sealers tested.

There were statistically significant differences between sealers and control groups $(p<0.05)$ in all mineralization parameters, independent of diabetic status. Mineralized areas, as determined by positive von Kossa staining and the presence of birefringent

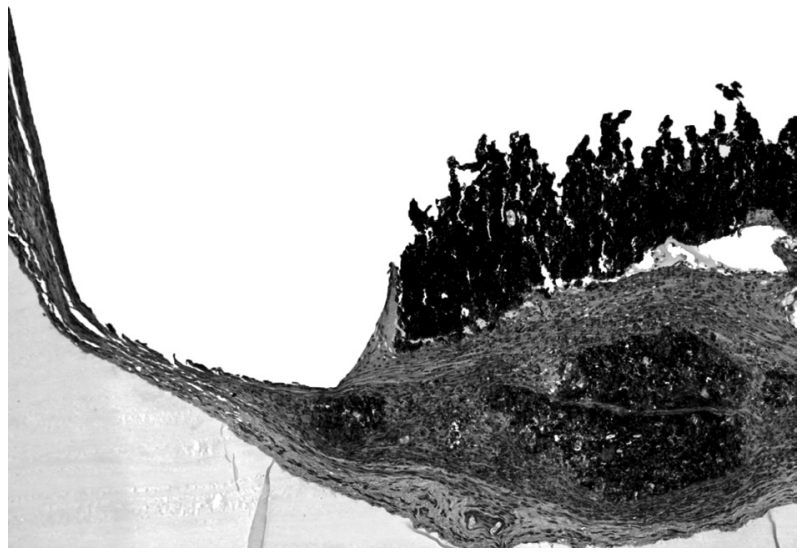

Figure 4. Inflammatory response in diabetic Sealapex group at day 30: moderate inflammatory cell infiltration (hematoxylin-eosin, 10X).

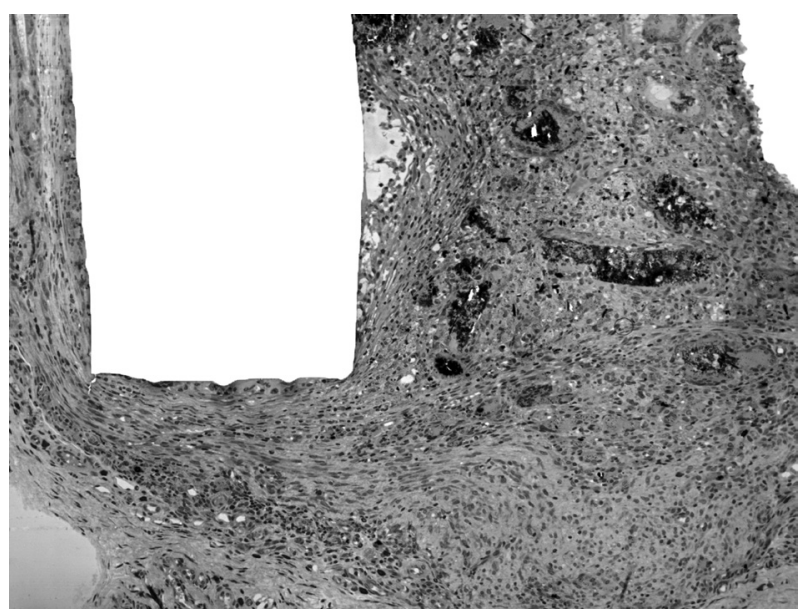

Figure 6. Inflammatory response in diabetic MTA Fillapex group at day 30: presence of a mild inflammatory cell infiltration consisting of macrophages and lymphocytes after 30 days (hematoxylin-eosin, 10X). 
structures, were seen around the tubes with sealers, with no significant difference related to diabetes $(p>0.05)$. On day 30, Sealape ${ }^{\circledR}$ showed more Von Kossa-positive areas than MTA Fillapex ${ }^{\circledR}(\mathrm{p}<0.05)$ independent of the diabetic condition.

The fluorescence intensity between each material and control group was significantly different and was independent of the fluorochrome and diabetic condition $(p<0.05)$. Moreover, there was no statistically significant difference between Sealape ${ }^{\circledR}$ and MTA Fillapex ${ }^{\circledast}$ group for all fluorochromes $(p>0.05)$ independent of the diabetic condition.

Table shows the data of inflammatory response, necrosis, von Kossa staining and fluorescence intensity of calcein, alizarin, or oxytetracycline.

\section{Discussion}

Several methods have been used to evaluate the biocompatibility of endodontic sealers and one of the widely accepted methods is the implantation of polyethylene tubes into the subcutaneous connective tissue of rats. ${ }^{14,20}$
Diabetic rat models have been developed to better understand diabetes. ${ }^{5,21}$ In the present study, Alloxan was the agent of choice to reproduce diabetic condition in rats; ${ }^{15}$ it exerts direct cytotoxic action on the pancreas inhibiting the production of insulin and causing severe hyperglycemia in the animal. ${ }^{22}$ Hyperglycemia increases the levels of systemic inflammatory markers ${ }^{2}$ impairing the wound healing process; it also contributes to systemic and oral manifestations, which have a direct effect on dental pulp integrity.,

In the present study, the inflammatory reaction observed for the control group was similar to previously reported findings of absence of Von Kossa-positive areas and structures birefringent to polarized light and basal fluorescence intensity. ${ }^{12,20}$

MTA Fillapex ${ }^{\circledast}$ induced a mild inflammatory response, which is in agreement with previously reported findings. ${ }^{12}$ Our findings disagree with those of another study that showed that MTA Fillapex ${ }^{\circledast}$ produces intense inflammatory response ${ }^{23}$ and has a severe cytotoxic action. ${ }^{24}$

Table 1. Number of samples in each group categorized according to the inflammatory score and median of samples in each group categorized by necrosis, presence of mineralization, and fluorescence intensity.

\begin{tabular}{|c|c|c|c|c|c|c|c|c|c|c|}
\hline \multirow{3}{*}{ Groups/ Time } & \multirow{3}{*}{ Material } & \multicolumn{4}{|c|}{ Inflammation (Score) } & \multirow{3}{*}{ Necrosis } & \multicolumn{4}{|c|}{ Presence of mineralization } \\
\hline & & \multirow[t]{2}{*}{0} & \multirow[t]{2}{*}{1} & \multirow[t]{2}{*}{2} & \multirow[t]{2}{*}{3} & & \multirow{2}{*}{ Van Koss } & \multicolumn{3}{|c|}{ Fluorescence Intensity } \\
\hline & & & & & & & & Calcein & Alizarin & Oxytretacycline \\
\hline \multirow[t]{3}{*}{ Non-Diabetic (07 days) } & Control & 0 & 6 & 0 & $0^{1}$ & $0^{1}$ & $0^{1}$ & - & - & - \\
\hline & Sealapex ${ }^{\circledR}$ & 0 & 2 & 4 & $0^{2}$ & $10197,1^{2}$ & $260652,1^{2}$ & - & - & - \\
\hline & MTA Fillapex ${ }^{\circledast}$ & 0 & 0 & 6 & $0^{2}$ & $2012,8^{2}$ & $152732,1^{2}$ & - & - & - \\
\hline \multirow[t]{3}{*}{ Diabetic (07 days) } & Control & 0 & 6 & 0 & $0^{1}$ & $0^{1}$ & $0^{1}$ & - & - & - \\
\hline & Sealapex ${ }^{\circledR}$ & 0 & 2 & 4 & $0^{2}$ & $6017,3^{2}$ & $158667,0^{2}$ & - & - & - \\
\hline & MTA Fillapex ${ }^{\circledR}$ & 0 & 1 & 5 & $0^{2}$ & $18873.0^{2}$ & $130204,3^{2}$ & - & - & - \\
\hline \multirow[t]{3}{*}{ Non-Diabetic (30 days) } & Control & 0 & 5 & 1 & $0^{1}$ & $0^{1}$ & $0^{1}$ & $43,858^{a 1}$ & $25,349^{a 1}$ & $37,957^{a 1}$ \\
\hline & Sealapex ${ }^{\circledR}$ & 0 & 1 & 4 & $1^{2}$ & $0^{1}$ & $523301,5^{2}$ & $122,145^{\mathrm{a} 2}$ & $120,351^{a 2}$ & $80,986^{a 2}$ \\
\hline & MTA Fillapex ${ }^{\circledR}$ & 0 & 4 & 2 & $0^{2}$ & $0^{1}$ & $198983,3^{3}$ & $84,357^{a 2}$ & $70,263^{a 2}$ & $74,136^{\mathrm{a} 2}$ \\
\hline \multirow[t]{3}{*}{ Diabetic (30 days) } & Control & 0 & 4 & 2 & $0^{1}$ & $0^{1}$ & $0^{1}$ & $46,469^{a 1}$ & $25,549^{a 1}$ & $31,595^{a 1}$ \\
\hline & Sealapex ${ }^{\circledR}$ & 0 & 0 & 4 & $2^{2}$ & $0^{1}$ & $568201,8^{2}$ & $107,426^{a 2}$ & $105,678^{a 2}$ & $90,154^{\mathrm{a} 2}$ \\
\hline & MTA Fillapex ${ }^{\circledR}$ & 0 & 4 & 2 & $0^{2}$ & $0^{1}$ & $347460,1^{3}$ & $94,227^{\mathrm{a} 2}$ & $96,031^{\mathrm{a} 2}$ & $74,048^{a 2}$ \\
\hline
\end{tabular}

Score: 0 : none or few inflammatory cells and no reaction; $1:<25$ cells and mild reaction; 2 : between 25 and 125 cells and moderate reaction; $3: 125$ or more cells and severe reaction.

The areas of mineralization and necrosis were measured in $\mu \mathrm{m} 2$.

Same letters and numbers indicate no statistical difference among the groups in row and columns respectively $(p>0.05)$. 
In this study, Sealapex ${ }^{\circledast}$ showed a moderate inflammatory response at all time points evaluated. Similar results were observed in other studies that suggest that alterations in the original formulation (replacement of the radiopacifier and increase of shelf-life) of this sealer could most likely promote marked inflammatory infiltration. ${ }^{10,25}$ However, the satisfactory biocompatibility and mild inflammatory reaction observed in previous studies ${ }^{7,8}$ were not observed in this study.

Only at day 30, Sealapex ${ }^{\circledast}$ showed more Von Kossa-positive areas than MTA Fillapex ${ }^{\circledast}(p<0.05)$ independent of the diabetic condition. The high solubility of Sealapex ${ }^{\circledR}$ and its ability to release more calcium and hydroxyl ions might increase the formation of mineralized tissue. ${ }^{26}$

Sealape ${ }^{\circledR}$ and MTA Fillape ${ }^{\circledR}$ are endodontic sealers with chemical properties that favor healing process. ${ }^{8,12,14,20}$ Calcium oxide is one of the main components of these sealers. In the presence of tissue fluids, calcium oxide forms calcium hydroxide, leading to high $\mathrm{pH}$, high solubility, and marked release of $\mathrm{Ca}^{+2}$ and $\mathrm{OH}^{-}$ions. ${ }^{12,27}$ The high $\mathrm{pH}$ may also neutralize the acids secreted by osteoclasts, and this may help prevent further destruction of mineralized tissue. ${ }^{24}$ These biologic activities can explain the presence of Von Kossa-positive areas, birefringent structures to polarized light, and increased fluorescence intensity.

The host response to materials in contact with tissue is complex, dependent on innate immune responses, nonspecific, and occurs in the surrounding tissue. Depending on the composition of sealers, all materials might induce some signaling pathways stimulating the expression of pro inflammatory cytokines and prostaglandins

\section{References}

1. American Diabetes Association. Diagnosis and classification of diabetes mellitus. Diabetes Care. 2013;36(Suppl 1);S67-74. doi:10.2337/dc13-S067

2. Graves DT, Liu R, Oates TW. Diabetes-enhanced inflammation and apoptosis: impact on periodontal pathosis. Periodontol 2000. 2007;45(1):128-37. doi:10.1111/j.1600-0757.2007.00219.x that are involved in initiation of the inflammatory process and that may contribute to a sequence of healing events. ${ }^{28,29}$ Many studies have shown that the inflammatory state produces an unfavorable environment for angiogenesis, cellular proliferation, and wound healing., ${ }^{4,5}$

The hyperglycemia caused by DM did not influence the inflammatory response or the mineralization capacity of sealers on any of the parameters investigated. There was no evidence of the direct correlation between mineralized tissue formation and inflammatory response in diabetes. These results might be attributed to various satisfactory characteristics of calcium hydroxide-based sealer, ${ }^{7,8,12}$ in our previous study, diabetic conditions were not found to influence the mineralization ability of or inflammatory response to MTA. ${ }^{23}$

Our findings are in disagreement with those of previous studies that showed that DM altered various functions of the immune system and is associated with delayed healing, predisposition to chronic inflammation, diminished tissue repair capacity, and alteration of the inflammatory response., ${ }^{4,5}$ There are conflicting data to suggest that the relationship of DM and biocompatibility is not yet completely understood, and other studies using different methods are warranted.

\section{Conclusion}

In conclusion, DM was not found to influence the tissue response or mineralization stimulated by Sealapex ${ }^{\circledR}$ or MTA Fillapex ${ }^{\circledR}$.

\section{Acknowledgments}

The authors thank FAPESP (Fundação de Amparo a Pesquisa do Estado de São Paulo, Brazil) for financial support.

3. Delamaire M, Maugendre D, Moreno M, Le Goff MC, Allannic H, Genetet B. Impaired leukocyte functions in diabetic patients. Diabet Med.1997;14(1):29-34. doi:10.1002/ (SICI)1096-9136(199701)14:1<29::AID-DIA300>3.0.CO;2-V

4. Garber SE, Shabahang S, Escher AP, Torabinejad M. The effect of hyperglycemia on pulpal healing in rats. J Endod. 2009;35(1):60-2. doi:10.1016/j.joen.2008.09.010 
5. Kohsaka T, Kumazawa M, Yamasaki M, Nakamura H. Periapical lesions with streptozotocin-induced diabetes. J Endod. 1996;22(8):418-21. doi:10.1016/S0099-2399(96)80243-3

6. Fouad AF. Diabetes mellitus as a modulating factor of endodontic infections. J Dent Educ. 2003;67(4):459-67.

7. Silva LAB, Leonardo RT, Faccioli LH, Figueiredo F. Inflammatory response to calcium hydroxide based root canal sealers. J Endod. 1997;23(2):86-90. doi:10.1016/S0099-2399(97)80251-8

8. Holland R, Souza V. Ability of a new calcium hydroxide root canal filling material to induce hard tissue formation. $\mathrm{J}$ Endod. 1985;11(12):535-43. doi:10.1016/S0099-2399(85)80199-0

9. Tanomaru JM, Tanomaru-Filho M, Hotta J, Watanabe E, Ito IY. Antimicrobial activity of endodontic sealers based on calcium hydroxide and MTA. Acta Odontol Latinoam. 2008;21(2):147-51.

10. Leonardo MR, Barnett F, Debelian GJ, Lima RKP, Silva LAB. Root canal adhesive filling in dogs' teeth with or without coronal restoration: a histopathological evaluation. J Endod. 2007;33(11):1299-303. doi:10.1016/j.joen.2007.07.037

11. Cañadas PS, Berástegui E, Gaton-Hernández P, Silva LA, Leite GA, Silva RS. Physicochemical properties and interfacial adaptation of root canal sealers. Braz Dent J. 2014; 25(5):435-41. doi:10.1590/0103-6440201300037

12. Gomes-Filho JE, Watanabe S, Lodi CS, Cintra LTA, Nery MJ, Otoboni Filho JA, et al. Rat tissue reaction to MTA FILLAPEX ${ }^{\circledR}$. Dent Traumatol. 2012;28(6):452-6. doi:10.1111/j.1600-9657.2011.01096.x

13. Morgental RD, Vier-Pelisser FV, Oliveira SD, Antunes FC, Cogo DM, Kopper PM. Antibacterial activity of two MTA-based root canal sealers. Int Endod J. 2011;44(12):1128-33. doi:10.1111/j.1365-2591.2011.01931.x

14. Salles LP, Gomes-Cornélio AL, Guimarães FC, Herrera BS, Bao $\mathrm{SN}$, Rossa-Junior $\mathrm{C}$, et al. Mineral trioxide aggregate-based endodontic sealer stimulates hydroxyapatite nucleation in human osteoblast-like cell culture. J Endod. 2012;38(7):971-6. doi:10.1016/j.joen.2012.02.018

15. Salil G, Nevin KG, Rajamohan T. Arginine rich coconut kernel protein modulates diabetes in Alloxan treated rats. Chem Biol Interact. 2011 Jan 15;189(1-2):107-11. doi:10.1016/j.cbi.2010.10.015

16. Astrand P, Carlsson GE. Changes in the alveolar process after extractions in the white rat. A histologic and fluorescent microscopic study. Acta Odontol Scand. 1969;27(1):113-27. doi:10.3109/00016356909033583

17. American National Standards Institute. Revised American National Standards Institute American Dental Association Document No. 41 for recommended standard practices for biological evaluation of dental materials. New York: American National Standards Institute; 1979.

18. Gomes-Filho JE, Gomes BPFA, Zaia AA, Novaes PD, Souza-Filho FJ. Glycol Methacrylate: an alternative method for embedding subcutaneous implants. J Endod. 2001;27(4):266-8. doi:10.1097/00004770-200104000-00005

19. Federation Dentaire International Recommended standart practices for biological evaluation of dental materials. FDI Commission on Dental Materials, Equipment, and Theropeutics. Part 4.11: subcutaneous implantation test. Int Dent J. 1980;30:173-4.

20. Holland R, Souza V, Nery MJ, Otoboni-Filho JA, Bernabé PFE, Dezan-Júnior E. Reaction of rat connective tissue to implanted dentin tubes filled with mineral trioxide aggregate or calcium hydroxide. J Endod. 1999;25(3):161-6. doi:10.1016/S0099-2399(99)80134-4

21. Gomes-Filho JE, Queiroz IOA, Watanabe S, Santos LMS, Lodi CS, Okamoto R, et al. Influence of diabetes mellitus on tissue response to MTA and its ability to stimulate mineralization. Dent Traumatol. 2015;31(1):67-72. doi:10.1111/edt.12130

22. Szkudelski T. The mechanism of alloxan and streptozotocin action in B cells of the rat pancreas. Physiol Res. 2001;50(6):537-46.

23. Tavares CO, Böttcher DE, Assmann E, Kopper PM, Figueiredo JA, Grecca FS, et al. Tissue reactions to a new mineral trioxide aggregate-containing endodontic sealer. J Endod. 2013;39(5):653-7. doi:10.1016/j.joen.2012.10.009

24. Silva EJNL, Rosa TP, Herrera DR, Jacinto RC, Gomes BPFA, Zaia AA. Evaluation of cytotoxicity and physicochemical properties of calcium silicate-based endodontic sealer MTA Fillapex. J Endod. 2013;39(2):274-7. doi:10.1016/j.joen.2012.06.030

25. Silva-Herzog D, Ramírez T, Mora J, Pozos AJ, Silva LAB, Silva RAB, et al. Preliminary study of the inflammatory response to subcutaneous implantation of three root canal sealers. Int Endod J. 2011;44(5):440-6. doi:10.1111/j.1365-2591.2011.01849.x

26. Tagger M, Tagger E, Kfir A. Release of calcium and hydroxyl ions from set endodontic sealers containing calcium hydroxide. J Endod. 1988;14(12):588-91. doi:10.1016/S0099-2399(88)80055-4

27. Borges RP, Sousa-Neto MD, Versiani MA, Rached-Júnior FA, De-Deus G, Miranda CES, et al. Changes in the surface of four calcium silicate-containing endodontic materials and an epoxy resin-based sealer after a solubility test. Int Endod J. 2012; 45(5):419-28. doi:10.1111/j.1365-2591.2011.01992.x

28. Reyes-Carmona JF, Santos ARS, Figueiredo CP, Felippe MS, Felippe WT, Cordeiro MM. In vivo host interactions with mineral trioxide aggregate and calcium hydroxide: inflammatory molecular signaling assessment. J Endod. 2011;37(9):1225-35. doi:10.1016/j.joen.2011.05.031

29. Schutte RJ, Xie L, Klitzman B, Rechert WM. In vivo cytokine-associated responses to biomaterials. Biomaterials. 2009;30(2):160-8. doi:10.1016/j.biomaterials.2008.09.026 